EESTI NSV TEADUSTE AKADEEMIA TOIMETISED. VI KÖDE

BIOLOOGILINE SEERIA. 1957, NR. 3

ИЗВЕСТИЯ АКАДЕМИИ НАУК ЭСТОНСКОИ ССР. ТОМ VI

СЕРИЯ БНОЛОГИЧЕСКАЯ. 1957, № 3

\title{
LESTA SIGIMISBIOLOOGIAST LÄÄNEMERE IDAOSAS
}

\section{N. MIKELSAAR}

Läänemere tugevasti magestunud idaosas on lesta (Pleuronectes flesus trachurus Duncker) sigimisolud tema looduslike varude kujunemisel suure tähtsusega.

Nii varasemate uurimisreiside kui ka viimase Oleliidulise Merekalamajanduse ja Okeanograafia Teadusliku Uurimise Instituudi (VNIRO) Läänemere uurimise ekspeditsiooni materjalid näitavad, et Läänemeres asub rida lesta koelmuid süvikute piirkondades. Kõige põhjapoolsemaks neist on seniste andmete järgi Gotlandi süviku piirkond [?, 2]. Rea aastate kestel Eesti NSV rannikuvetes teostatud lestade märgistamise tulemustest* ilmnes, et enamik siin suguküpseks saanud lestadest rändab üldiselt läände, avamere suunas, kusjuures paljud isendid rändavad vahetult Gotlandi süviku suunas.** Viimane on ilmselt üheks tähtsamaks kudemiskohaks Eesti NSV rannikuvetes karjatuvatele lestadele.

Nagu näitas VNIRO hiljutine ekspeditsioon, ei piirdu lesta süvikukoelmud Läänemere idaosas ainult Gotlandi süvikuga. Ajavahemikus 20.-23. aprillini 1955. aastal avastas VNIRO uurimislaev mitmes kohas Gotlandi süvikust kaugemal pōhja pool kuni sügavate piirkondadeni (sügavus üle $100 \mathrm{~m}$ ) lääne pool Hiiumaad lestaparvi, mis koosnesid 68-100\% suguküpsest, jooksvate suguproduktidega isendist (L. Rannaku analüüsid). Uhtlasi püüti põhja pool, kuni 59-nda laiuskraadini, ka lesta pelaagilist marja (meie poolt läbivaadatud marjaterad olid püütud zooplanktonivôrguga).

Lesta mari on oma iseloomult pelaagiline ja vajab arenemiseks soolast vett. Sandman ${ }^{[8} 7$ tõestas esimesena, et lesta mari võib areneda ka Läänemere kirdeosa magestunud vees. Sel juhul langeb mari põhja või hõljub tihedalt selle läheduses. Põhja langevat marja on leitud ka Läänemere lõunaosas - Oderbankil ja Mittelbankil [ $\left.{ }^{3}\right]$.

Piki Eesti NSV rannikut, eriti Soome lahes, on kaluritel teada rida kitsamaid piirkondi, kus kevadeti on võimalik võrkudega püüda suguküpseid, jooksvate suguproduktidega lesti. Kõik lesta koelmuteks peetavad kohad, välja arvatud Tallinnakivi madalik, asuvad ranna lähedal ja nende sügavus kõigub 4-15 meetri vahel. Tüüpiline on veel niisuguste kohtade paiknemine saarte ja poolsaarte neil külgedel, mis asetsevad hoovustele vastu. See asjaolu tagab pideva veevahetuse ja mudavaba põhjapinna. Tavaliselt on sellised kohad kivised.

* Seni avaldamata materjalid.

** Kuna lestapüük toimub peamiselt rannikuvööndis, siis on märgistatud lestade väljapüügid süvikute piirkondadest väga haruldased. 
Eesti NSV vetes elunevate lestade sigimisbioloogia uurimiseks, eriti nende rannalähedaste koelmute väljaselgitamiseks, rajas VNIRO Eesti osakond 1949. aastal Soome lahes, Tallinnast põhja pool asuvas rannikupunktis Rohuneemel ajutise välilaboratooriumi.

Käesoleva artikli autori juhtimisel on nimetatud laboratoorium kogunud materjale, mis kinnitavad täiel määral oletatud rannalähedaste koelmute olemasolu.

Ihtüoplanktoni materjale koguti ajavahemikus 13. maist kuni 10 . juunini ja 30 . juunist kuni 14. septembrini 1949. aastal. Neid materjale kogus ja töötas läbi J. Kruusel. Peamiseks vaatlusalaks valiti meri Aegna saare ümbruses, eriti saarest loode pool asuva madaliku ümbrus. Seda piirkonda peavad kalurid üheks lesta koelmuks. Lesta koelmute otsimiseks Soome lahe idapoolsemates punktides korraldati 8. juunil 1949. aastal pikem reis kuni Juminda poolsaare tipuni (geograafil. pikkus $25^{\circ} 30^{\prime}$ ), kusjuures teel vōeti proove Malusi ja Rammu saare piirkonnas. Peale selle võeti kahel korral proove neljas erineva sügavusega punktis Randvere lahes ja Karpova madalikul (samas lahes).

Oldse koguti ja analüüsiti 128 proovi, nendest 61 Rassi maimutraaliga 2 kuni 55 meetri sügavuselt, 44 marjavõrguga vertikaalselt kuni $85 \mathrm{~m}$ sügavuseni ja 23 marjavōrguga horisontaalselt vee pinnakihist. Materjal fikseeriti kohe $2 \%$-lises formaliinis.

Katsepüükide tulemused on esitatud tabelis 1. Siin on antud ainult need proovid, milles leidus lesta marja*.

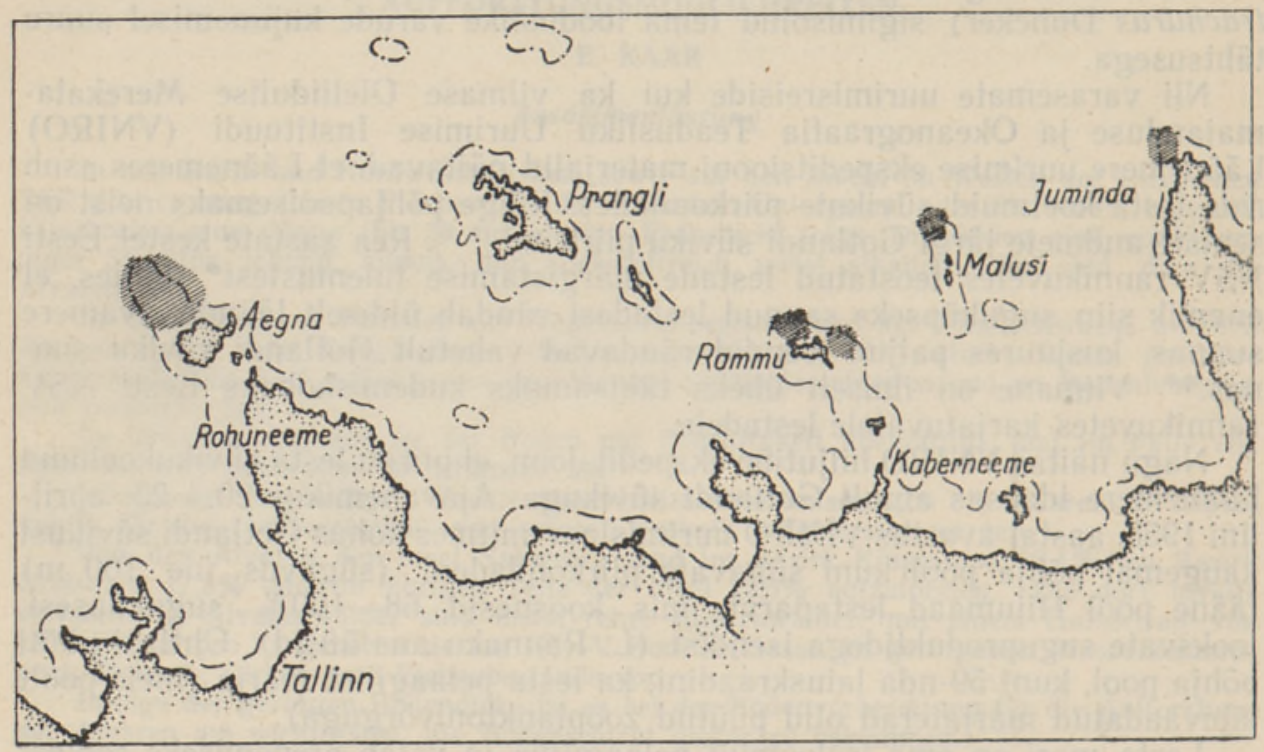

Joon. 1. Piirkonnad Soome lahes, kust leiti lesta marjateri (viirutatud). Места находок икринок речной камбалы в Финском заливе (заштриховано).

Välilaboratooriumi töö tulemused lesta koelmute otsimisel võib kokku võtta järgmiselt:

1. Soome lahe neljas, geograafiliselt erinevas, kalurite poolt lestade koelmuteks peetud kohas leiti suuremal või vähemal arvul lestade marjateri. See asjaolu kinnitas kalurite tähelepanekuid koelmute esinemisest, millest idapoolseim asub Juminda poolsaare tipu kohal (joon. 1).

* Uksikuid katsepüüke lesta marja otsimiseks tegi autor Rassi maimutraaliga juba 26. mail ja 28. juunil 1945. aastal Prangli saare juures, kuid tulemusteta. Vôimalik, et seda põhjustas aja ja püügikoha ebaōnnestunud valik, 
Lesta marja püügid Soome lahes 1949. aastal

(Püünis: Rassi maimutraal; aeg $5 \mathrm{~min}$.)

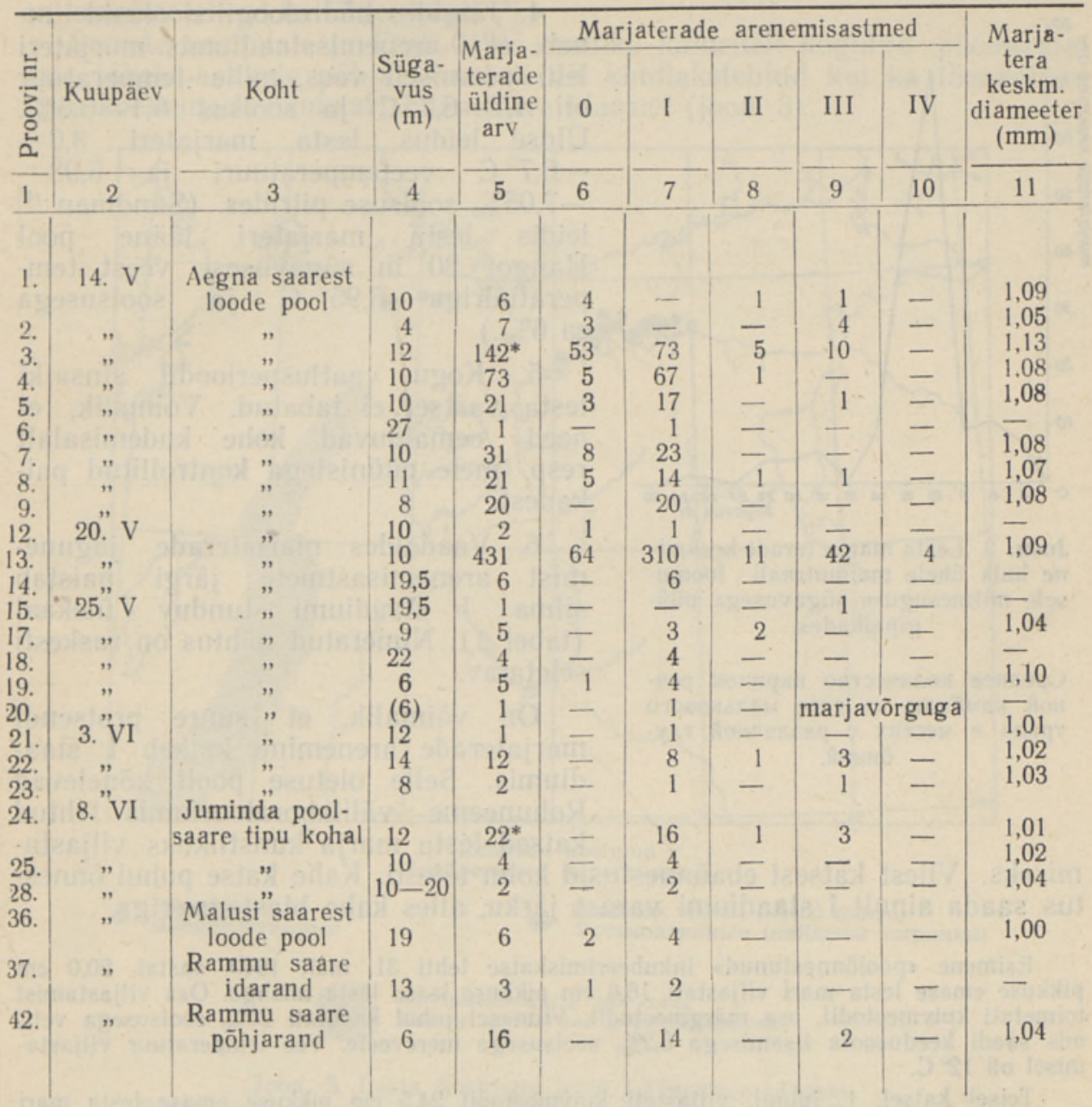

* Ohel marjateral proovist nr. 3 ja kahel marjateral proovist nr. 24 polnud võimalik arenemisastmeid määrata, mistōttu nad esinevad ainult lahtris 5 .

2. Marjaterad püüti kõik (ühe küsitava erandiga) ainult Rassi traaliga*, s. o. põhjast või põhjalähedastest veekihtidest. Kõ̃ik proovid marjavõrguga nii veesambast kui ka pinnalt andsid lesta marjade suhtes negatiivseid tulemusi.

Erandiks on üks proov (nr. 20), kus üks marjatera püüti $6 \mathrm{~m}$ sügavusest marjavōrguga. On pōhjust arvata, et see marjatera paisati pōhjalt veesambasse, sest just enne oli samas kohas püütud Rassi traaliga.

Tuleb veel märkida, et ka ida pool Aegna saart ühest $85 \mathrm{~m}$ sügavusest punktist saadud planktonivõrguproovidesse, mis olid vōetud veesamba kõigist horisontidest, ei sattunud ainustki lesta marjatera ega maimu perioodil kevadest kuni sügiseni, kusjuures proove oli vōetud selle aja jooksul regulaarselt umbes kümnepäevaste vaheaegadega.

* Rassi traali mōōtmed (sisemised) olid: laius $60 \mathrm{~cm}$, kōrgus $20 \mathrm{~cm}$. Veo kestus kōigi proovide puhul oli 5 minutit. 
3. Nagu nähtub tabelist 1 , saadi lesta marja 4-22 (27) m sügavuse piiridest. Kõige rikkamad marjaterade poolest olid proovid $10 \mathrm{~m}$ sügavusega punktidest (joon. 2).

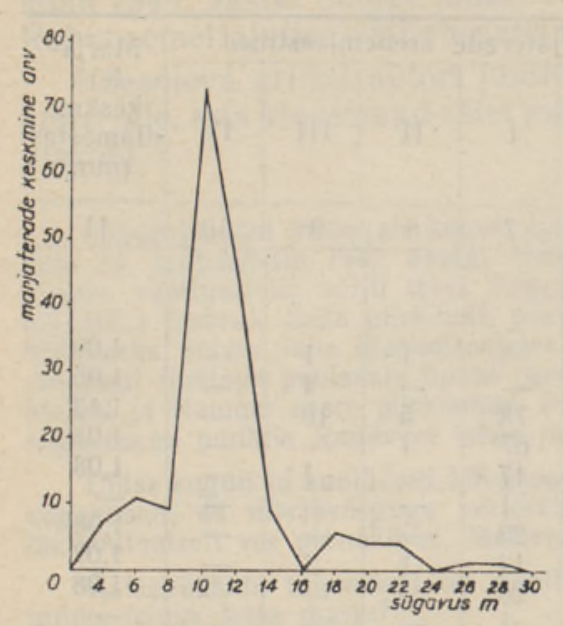

Joon. 2. Lesta marja terade keskmine hulk ühele maimutraali loomusele mitmesuguse sügavusega püügipaikades.

Среднее количество икринок речной камбалы на тяге малькового трала в местах с различной глубиной.

4. Jälgides hüdroloogilisi olusid ilmneb, et 0 -arenemisstaadiumis marjateri leiti peamiselt vees, mille temperatuur oli $4,7-6,7^{\circ} \mathrm{C}$ ja soolsus $6,1-6,6 \%$. Uldse leidus lesta marjateri $3,0-$ $-6,7^{\circ} \mathrm{C}$ veetemperatuuri ja $5,98-$ $-7,05 \%$ soolsuse piirides. (Sandman $\left.{ }^{8}\right]$ leidis lesta marjateri lääne pool Hangot $20 \mathrm{~m}$ sügavusest veest temperatuuriga $6,95^{\circ} \mathrm{C}$ ja soolsusega ca $6 \%$.)

5. Kogu vaatlusperioodil ainsatki lesta vastset ei tabatud. Võimalik, et need eemalduvad kohe kudemisalalt resp. meie püünistega kontrollitud paikadest.

6. Vaadeldes marjaterade jagunemist arenemisastmete järgi paistab silma I staadiumi tunduv ülekaal (tabel 1). Nimetatud nähtus on raskesti seletatav.

On võimalik, et suure protsendi marjaterade arenemine katkeb I staadiumis. Selle oletuse poolt kõnelevad Rohuneeme välilaboratooriumis tehtud katsed lesta marja kunstlikuks viljastamiseks. Viiest katsest ebaõnnestusid kolm täiesti. Kahe katse puhul ônnestus saada ainult I staadiumi varast järku, alles kahe blastomeeriga.

Esimene «poolōnnestunud» inkubeerimiskatse tehti 31 . mail 1949 . aastal, $20,0 \mathrm{~cm}$ pikkuse emase lesta mari viljastati $16,6 \mathrm{~cm}$ pikkuse isase lesta niisaga. Osa viljastamist toimetati kuivmeetodil, osa märgmeetodil. Viimasel juhul kasutati $20 \%$ soolsusega vett, mis saadi keedusoola lisamisega $6,2 \%$ soolsusega mereveele. Vee temperatuur viljastamisel oli $12^{\circ} \mathrm{C}$.

Teisel katsel, 1. juunil, viljastati kuivmeetodil $24,5 \mathrm{~cm}$ pikkuse emase lesta mari $19,9 \mathrm{~cm}$ pikkuse isase lesta niisaga. Katsel kasutati $6,2 \%$ soolsusega looduslikku merevett.

Arenemistunnustega marjateri saadi kõigi kolme variandi puhul, kusjuures esimesed lõigustumistunnustega marjaterad leiti 2 tundi pärast viljastamist.

Peale võimalike ebasoodsate muudatuste termilises ja soolsusrežiimis tuleb arvestada seda, et nii looduslikult kui ka kunstlikult viljastatud marjaterade arenemisele võib eespoolkirjeldatud oludes avaldada negatiivset mõju veel kontakt substraadiga.

Lesta marjaterade hilisemate staadiumide vähesuse võiks panna ka marja vaenlaste intensiivse tegevuse arvele. Viimaste suhtes on rannikumadalikkudele koetud mari tõenäoliselt enam ohustatud kui vabas veemassis hõljuv mari. Võib oletada, et vanemas arenemisjärgus marjaterad säilivad ainult kaitstuna kivide all, kuhu nad kantakse hoovustega. Vastavad otsesed vaatlused ja andmed, mis tõestaksid marjavaenlaste arvukamat esinemist lestade rannikukoelmutel, aga puuduvad.

Jääb üle näiliselt kõige tõepärasem oletus, nimelt: marja arenemise katkemine nii looduslikes kui ka kunstlikes tingimustes lubab arvata, et nii ühel kui ka teisel juhul viljastamist tegelikult ei toimugi, vaid toimub ainult 
partenogeneetilisele arenemisele stimuleerimine, nagu seda on paljude kalaliikide juures esile kutsunud mitmed uurijad [5]. (Rannikul kudevate lestade marja madalat viljastatuse määra (umbes 33\%) Hangost lääne pool on konstateerinud ka Ehrenbaum ${ }^{[8]}$.)

Seniste uurimiste ja Eesti NSV ranniku kaluritelt kogutud pikemaajaliste tähelepanekute põhjal koostati nii kindlakstehtud kui ka tõenäoliste lesta koelmute levikukaart Läänemere idaosas (joon. 3).

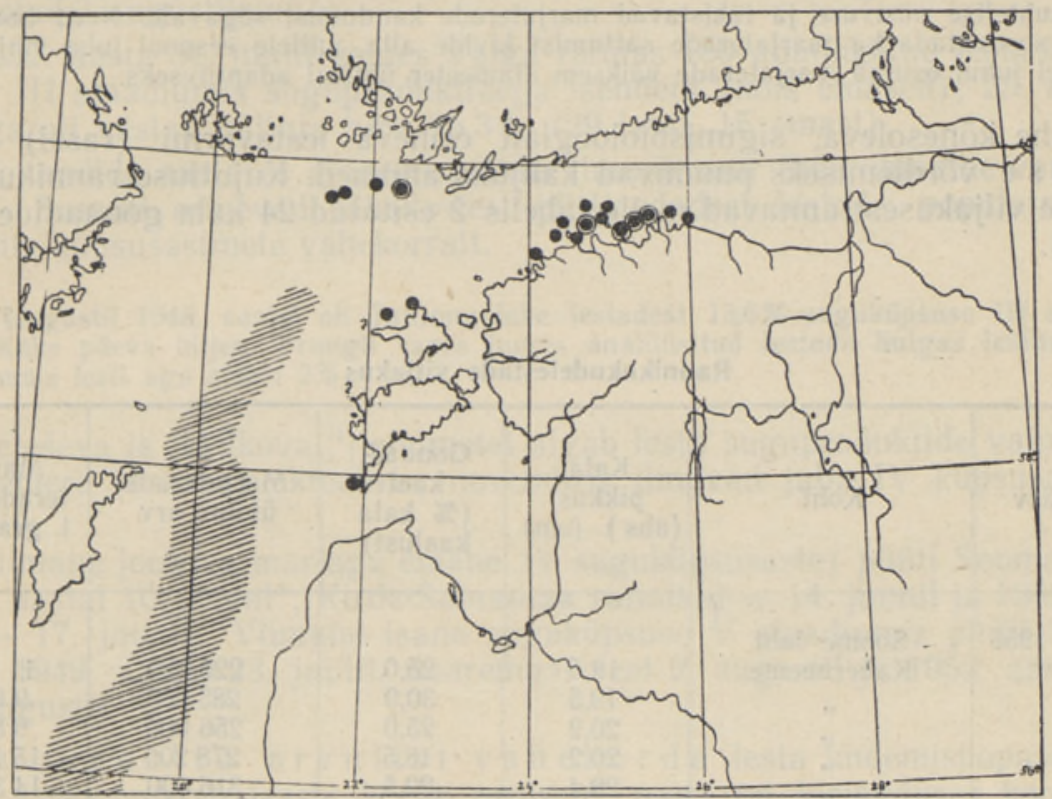

Ranniku koelmud

Прнбрежные нерестилища

Tōenäosed

Предполагаемые
- Kindlaks tehtud (leitud marja) Установленные (найдены икрннки)

Joon. 3. Lesta koelmute levik Läänemere idaosas.

Распределенне нерестилищ камбалы в восточной части Балтийского моря.

Pōhilisemad lahkuminekud süviku- ja rannikukoelmute vahel avalduvad peale erineva sügavuse veel erinevas valgustus-, temperatuuri- ja gaasiderežiimis. Erinevad on samuti vee soolsusrežiim ja vee liikumise, s. o. hoovuste olud - faktorid, mis määravad marja hõljumise tingimused. Lahkuminevad on ka biootilised tegurid: toit ja vaenlased.

Lestade kudemine süvikupiirkondades toimub üldiselt varem - aprillis ja mais, Soome lahe rannikumadalikel aga peamiselt mais-juunis.

Põhilisemaks morfoloogiliseks erinevuseks süviku- ja rannikukudelestade vahel on esimeste keskmiselt suurem selgroblülide ja uimekiirte arv $\left.{ }^{4}\right]$. Eriti silmapaistev on aga erinevus marjaterade mõootmetes. Marjaterade läbimõõt on süvikukudelestadel tunduvalt suurem kui rannikukudelestadel, kusjuures isegi viimaste maksimaalmõõtmed on alati väiksemad esimeste minimaalmõõtmetest.

Soome lahest püütud lesta marja terade keskmised mõōtmed üksikproovides on esitatud tabelis 1. Kõigi mōōdetud marjaterade keskmiseks diameetriks osutus $1,025 \mathrm{~mm}$, vähimaks $0,83 \mathrm{~mm}$, suurimaks $1,20 \mathrm{~mm}$ (J. Kruusel). Läänemere keskosast, Ventspilsi ja 
Liepaja kohal püütud süvikukudelestade marjaterade keskmiseks diameetriks saadi $1,36 \mathrm{~mm}$, vähimaks $1,27 \mathrm{~mm}$, suurimaks $\left.1,43 \mathrm{~mm}^{3}\right]$. 20,-23. aprillini 1955 . aastal lääne pool Hiiu- ja Saaremaad sügavatest vetest püütud lesta marjaterade diameeter kõikus $1,30-1,40 \mathrm{~mm}$ vahel.

Tuleb märkida, et rannikukudelesta väikesemōõtmelistel, demersaalsetel marjateradel on siiski teatav, kuigi väga lühiaegne, hõljumisvõime. Seda soodustavad hoovused, mis süvikuoludes puuduvad. Nimelt kasutab rannikukudelest marjaheitmiseks koelmuid poolsaarte ja saarte tippudel, kus esinevad pöörduvad hoovused, mis tekitavad vee ringliikumist. Seesugused hoovused kindlustavad arvatavasti koelmu veemasside omaduste suhtelise püsivuse ja takistavad marjaterade kandumist sügavale. Need hoovused vōivad soodustada ka marjaterade sattumist kivide alla, millele eespool juba vihjasime. Viimasel juhul osutub marjaterade väiksem diameeter ühtlasi adaptiivseks.

Kahe kõnesoleva, sigimisbioloogialt erineva lestavormi (rassi) vil j a kus e võrdlemiseks puuduvad kahjuks andmed. Kujutluse rannikukudelestade viljakusest annavad meile tabelis 2 esitatud 24 kala gonaadide analüüsid.

Tabel 2

Rannikukudelestade viljakus

\begin{tabular}{|c|c|c|c|c|c|}
\hline Kuupäev & Koht & $\begin{array}{c}\text { Kala } \\
\text { pikkus } \\
\text { (abs) (cm) }\end{array}$ & $\begin{array}{l}\text { Gonaadi } \\
\text { kaal } \\
\text { (\% kala } \\
\text { kaalust) }\end{array}$ & $\begin{array}{l}\text { Marjaterade } \\
\text { üldine arv }\end{array}$ & $\begin{array}{l}\text { Marja- } \\
\text { terade arv } \\
1 \text { grammis }\end{array}$ \\
\hline 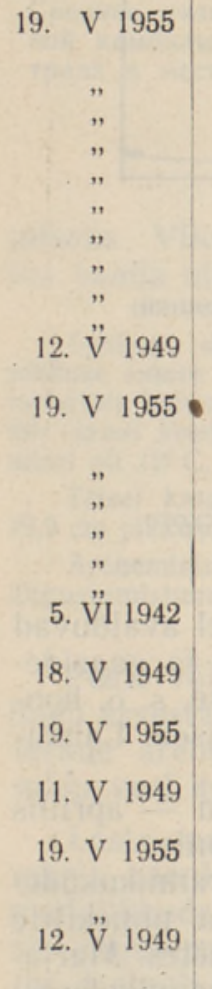 & $\begin{array}{c}\text { Soome laht } \\
\text { Kaberneeme } \\
", \\
", \\
", \\
\text { Soome laht } \\
\text { Aegna } \\
\text { Soome laht } \\
\text { Kaberneeme } \\
", \\
", \\
", \\
\text { Saaremaa } \\
\text { Sorve poolsaar } \\
\text { Soome laht } \\
\text { Aegna } \\
\text { Soome laht } \\
\text { Kaberneeme } \\
\text { Soome laht } \\
\text { Aegna } \\
\text { Soome laht } \\
\text { Kaberneeme } \\
\text { Soome laht } \\
\text { Aegna }\end{array}$ & $\begin{array}{l}18,5 \\
19,5 \\
20,2 \\
20,2 \\
20,4 \\
20,5 \\
20,6 \\
20,9 \\
21,2 \\
21,2 \\
\\
21,5 \\
\\
21,6 \\
22,8 \\
23,4 \\
23,6 \\
24,1 \\
24,5 \\
\\
25,7 \\
\\
27,0 \\
28,7 \\
\\
31,2 \\
31,8 \\
32,6 \\
\\
34,1\end{array}$ & $\begin{array}{l}25,0 \\
30,9 \\
25,0 \\
18,5 \\
22,5 \\
20,0 \\
28,6 \\
23,0 \\
22,5 \\
27,6 \\
27,5 \\
24,4 \\
29,4 \\
31,1 \\
28,6 \\
30,5 \\
27,8 \\
38,7 \\
27,3 \\
\\
35,5 \\
23,1 \\
38,0 \\
34,0 \\
20,7\end{array}$ & $\begin{array}{r}220320 \\
285200 \\
256000 \\
278200 \\
316800 \\
282900 \\
444300 \\
326890 \\
279000 \\
341040 \\
323332 \\
368500 \\
516100 \\
588000 \\
550000 \\
490000 \\
598850 \\
715500 \\
724627 \\
911200 \\
860000 \\
\\
2041000 \\
1820700 \\
1005695\end{array}$ & $\begin{array}{r}11535 \\
9609 \\
9804 \\
15127 \\
14367 \\
13497 \\
11140 \\
13706 \\
11259 \\
12938 \\
8645 \\
12628 \\
11336 \\
10297 \\
11520 \\
9909 \\
8636 \\
7376 \\
10485 \\
7005 \\
10455 \\
11460 \\
12077 \\
10753\end{array}$ \\
\hline
\end{tabular}

S u guküpsuse s a avut avad rannikukudelestade emased isendid nelja aasta, isased kolme aasta vanuselt. Vähim suguküps emane leiti $18,5 \mathrm{~cm}$ pikkune, vähim jooksvate suguproduktidega isane $15,2 \mathrm{~cm}$ pikkune (Soome laht, 12. V 1949). Süvikukudelestade suguküpsus algab samas 
vanuses ['] ja üksikutel eksemplaridel ka sama pikkuse juures. Oldiselt on aga nende mõōtmed veidi suuremad rannikukudelestade omadest.

Meie poolt 1949. aasta maist kuni detsembrini Soome lahes Rohunéemel tehtud korduvate analüüside alusel ja sama aasta juunist septembrini VNIRO teadusliku vaatleja poolt Loode-Saaremaal, Vaigu rannas tehtud analüüside alusel selgus, et üleminek suguküpsuse kolmandasse staadiumi, s. o. suguproduktide küpsemise algus, ilmneb nii isastel kui ka emastel lestadel augustikuus.

1952. aasta 31. juulil esines Vaigu rannas 150 analüüsitud lesta hulgas $\mathbf{7 , 3 \%}$ III staadiumis suguproduktidega isendeid (kõik emased); 25. augustil aga oli vastav näitaja juba $25,3 \%$ (29 isast, 15 emast).

Gonaadide aastases arenemistsüklis ilmneb suur individuaalne varieerumine. Samuti erinevad lähedastest piirkondadest lestade populatsioonid isendite küpsusastmete vahekorralt.

7. augustil 1948. aastal oli Tallinna lahe lestadest $13,6 \%$ suguküpsuse III staadiumis. Kaks päeva hiljem Prangli saare juures analüüsitud lestade hulgas leidus selles staadiumis lesti aga ainult $2 \%$.

Beteševa ja Kulikova [1] andmetel algab lesta suguproduktide valmimine Läänemere keskosas oktoobris; novembris ilmuvad juba IV küpsusastmes isendid.

Viimane jooksva marjaga emane (V suguküpsusaste) püüti Soome lahes 1949. aastal 10. juunil*, Kirde-Saaremaa rannikul - 14. juunil ja 1952. aastal - 17. juunil. Viimane isane suguküpsuse V staadiumis püüti Soome lahes 1949. aastal 23. juulil, Saaremaal veel 2. augustil ja 1952. aastal 11. augustil.

Sugupoolte arvulist vahekorda lesta kudemispopulatsioonides iseloomustab isaste kõrge protsent, nagu on kirjanduses korduvalt märgitud, sealhulgas ka Läänemere idaosa kohta [ []].

Aegna koelmu otsesest lähedusest Soome lahes 31. mail 1949. aastal võrguga püütud lestade hulgas oli $93 \%$ isaseid, kes olid valdavalt V küpsusastmes. 7. mail 1943. aastal Soome lahes Prangli saare rannikul oletatava koelmu piirkonnast püütud 225 lesta hulgas leidus 191 isast, s. o. $84,9 \%$.

Rannalähedase koelmu otseses naabruses teostatud püükides kõigub sugupoolte arvuline vahekord tugevasti, sõltudes tublisti sellest, kui suurel määral on proovi sattunud noored isendid või juba kudenud emased või käitumiselt erinevad süvikukudelestad. Paiguti on huvitav jälgida kudemisaegset sugupoolte vahekorra muutumis ${ }^{\dagger}$ seoses sügavusastmetega. Viimast illustreerib 22. mail 1943. aastal Hiiumadala läheduses kolmes erineva sügavusega kohas püütud saakide analüüs, mis on esitatud tabelis 3 .

Need püügid ei toimunud otseselt koelmualal, mida näitab ka isaste üldiselt väike protsent, kuid tabeli põhjal selgub, et rannalähedastes madalaveelistes kohtades, mis on oletatavatele koelmutele lähemal, tõusis isaste ja veel kudemata emaste protsent. Isaste protsent lestapopulatsioonides rannikukoelmute piirkonnas tõuseb, kui läheneda koelmutele nii horisontaal- kui ka vertikaalsuunas, kusjuures rannikukudelestad lähevad pärast kudemist sügavamale. Hiiumadala püügipiirkonna sügavaim koht $(24 \mathrm{~m})$ osutus antud ajal ka kõige kalarikkamaks.

Beteševa ja Kulikova [1] andmetel, mis kajastavad peamiselt süvikukudelestade käitumist, näitab isaste ja emaste vahekord Ventspilsi piirkonna lestasaakides, et juunis pärast kudemist tulevad randa emased, juulis mõnevõrra tasakaalustub sugupoolte suhe ja alates augustist suureneb isaste arv.

* Leidus isegi alles IV staadiumis isendeid. 
Sugupoolte arvuline vahekord lestapopulatsioonides Hiiumadala püügipiirkonna erineva sügavusega punktides

\begin{tabular}{|c|c|c|c|c|c|c|c|c|}
\hline 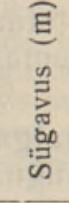 & 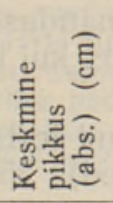 & $\begin{array}{l}\text { Minimaalne ja } \\
\text { maksimaalne } \\
\text { pikkus (cm) }\end{array}$ & 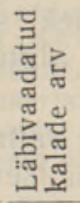 & 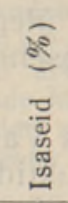 & 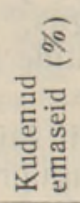 & 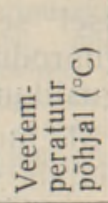 & 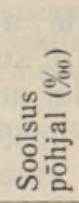 & 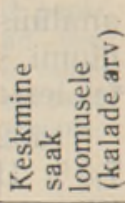 \\
\hline $\begin{array}{l}12,5 \\
17 \\
24\end{array}$ & $\begin{array}{l}25,8 \\
27,1 \\
29,0\end{array}$ & $\begin{array}{l}16,7-35,2 \\
16,0-36,6 \\
18,4-36,6^{* *}\end{array}$ & $\begin{array}{r}96 \\
228 \\
1636\end{array}$ & $\begin{array}{r}29,2 \\
25,9 \\
7,8\end{array}$ & $\begin{array}{l}23,5 \\
42,6 \\
69,5\end{array}$ & $\begin{array}{l}7,3 \\
2,9 \\
2,7\end{array}$ & $\begin{array}{l}7,54 \\
8,15 \\
7,67\end{array}$ & $\begin{array}{l}(96)^{*} \\
104 \\
285\end{array}$ \\
\hline
\end{tabular}

* Pole tegelikult keskmine, vaid ainsa loomuse saak.

** Mōōdetud 200 isendit.

Üldjoontes samasugune pilt ilmneb ka Eesti NSV ranniku lestasaakides, kus, otsustades morfoloogiliste andmete järgi, domineerivad samuti süvikukudelestad. Isaste hulga kasv saakides aasta teisel poolel toimub nimetatud autorite arvates emaste lahkumise tagajärjel suurema sügavusega paikadesse väljaspool töönduspiirkondi. Selle oletuse kasuks kõnelevad ka mõned meie katsed lestade märgistamisest.

Soome lahes (Toilas ja Pudisool) juulis ja augustis 3-6 m sügavusel märgistatud lestadest püüti kolm isendit välja oktoobris $27-30 \mathrm{~m}$ sügavuselt; need osutusid III küpsusstaadiumis olevateks emasteks.

Tuleb siiski konstateerida, et Läänemere kirdeosas on lestade sugupoolte arvulise suhte dünaamika üldiselt keerukam, kui seda võiks järeldada töönduslike saakide analüüsi alusel. Nii näiteks on tabeliga 3 teatavas vastuolus see asjaolu, et Soome lahes katseks korraldatud vỗrgupüükidel (18. ja 27. augustil ning 13. detsembril 1949. aastal) saadi sügavamast kohast alati rohkem isaseid. Proovid koosnesid peamiselt lestadest, kes oma morfoloogiliste tunnuste alusel kuulusid süvikukudelestade hulka. Nagu näitasid L. Rannaku analüüsid Läänemere avavetest 1955. aasta aprillis, võivad üksikasjalikumad varakevadised uurimistööd avamerel anda palju väärtuslikku materjali nii kõnesolevas kui ka teistes küsimustes.

Eelnevast järeldame, et Läänemere idaosa lestavarude hindamisel tuleb arvestada kaht sigimisbioloogialt erinevat (süvikul ja rannikul kudevat) rühmitust (rassi). Kas peale nende, koelmute asukohtade poolest selgesti erinevate lestarühmituste esineb Läänemere idaosas veel vahepealse iseloomuga koelmuid ja lestarühmitusi - seda ei selgu senikogutud sigimisbioloogilistest andmetest.

Süvikukude- ja rannikukudelestade koelmute erinev paigutus põhjustab erinevusi nende vastsete ja samasuviste ranniku üleskasvualadele «külvi» tingimustes. Teiselt poolt peab erinema ka täiskasvanud kalade käitumine, kes, sõltuvalt karjatusalade ja koelmute vahekaugusest, peavad sooritama pikemaid või lühemaid rändeid. Nii ühe kui teise protsessi lähemal tundmaõppimisel on suur tähtsus nende rühmituste bioloogia mõistmiseks. Eriti on vaja üksikasjalikumalt tundma õppida neid küsimusi, mis puutuvad marja ja vastsete külvisse. Kuigi on olemas juba teatavaid üldisi kogemusi lestade kunstlikus kasvatamises [ $\left.{ }^{9}\right]$, puuduvad siiski veel vajalikud konkreetsed andmed kas või näiteks perioodi kohta, mis on vajalik Lääne- 
mere idaosa lestade arenemiseks, alates marja viljastumisest ja lõpetades metamorfoosiga. On põhjust arvata, et selle perioodi kestusest sõltub suurel määral marjaterade ja vastsete arenemine. Pelaagiliste marjaterade ja vastsete arenemisaste (resp. omadused) võib olla nende randajõudmisel siinsetele oludele ve e I m itte vastav, või - kui nad on hoovuste poolt kaugeíe avamerele kantud - li iga vara metamorfoosini jõudnud. Nende vastuolude lahendamine kahes sumas loodusliku valiku teel on viinud kahe eespoolvaadeldud rühmituse väljakujunemisele. Silmas pidades Läänemere idaosa lestade suuri morfoloogilisi erinevusi ja rohkeid anomaaliaid tuleb järeldada, et nende rühmitusprotsess kahes peamises suunas praegu jätkub.

Rannikukudelestade mari peab kohanema juba väga varases staadiumis põhjaga, süvikukudelestade mari seevastu hõljumisega võimalikult kõrgemates, voogavates veekihtides. Süvikukudelestade vastsed aga peavad arendama võimalikult suuremat edasiliikumisvõimet.

\section{KIRJANDUS}

1. Бете ше в а Е. И. и К ул и ков а Е. Б., Речная камбала средней части Балтийского моря. Труды ВНИРО, т. XXVI, 1954.

2. К азанов а И. И., Материалы по размножению рыб Балтийского моря. Доклады ВНИРО, вып. 1, 1952.

3 Қаззанов И. И., Определитель икры и личинок рыб Балтийского моря и его заливов. Труды ВНИРО, т. XXVI, 1954.

4. Микельса ар Н. Ф., О геименении метода уравненных шкал при изучении внутривидовых группировок речной камбалы (Uhtlustatud skaalade meetodi kasutamisest lestade liigisiseste rühmituste uurimisel). Гидробиологические исследования. Институт зоологии и ботаники АН Эстонской ССР, 1957.

5. Пу чков Н. В., Физиология рыб. Москва, 1954, стр. 243.

6. G o t t b e rg, G., Kalojen sukupuolien väliset lukusuhteet. Kalastustentarkastajan Julkaisuja, 1918, Nr. 8 .

7. $\mathrm{Mielck}$-W. u. K ün ne, C., Fischbrut- und Plankton-Untersuchungen auf dem Reichsforschungsdampfer «Poseidon» in der Ostsee, Mai-Juni 1931. Wissensch. Meeresunters. N. F., Abt. Helgoland, Bd. 19, H. 3, 1935.

8. S a n d m a n, I. A., Kurzer Bericht über in Finnland ausgeführte Untersuchungen über den Flunder, den Steinbutt und den Kabeljau. Rapp. et Proc. - Verb., Vol. V, 1906.

9. U b is ch, L. von, Uber die Zahl der Flossenstrahlen bei Pleuronectes platessa, Pl. flesus und der Bastarde und Rückkreuzungen zwischen beiden Arten. Zool. Anzeiger, Bd. 151, H. 5-6, 1953.

Eesti NSV Teaduste Akadeemia

Zooloogia ja Botaanika Instituut

Saabus toimetusse

31. I 1957

\section{О БИОЛОГИИ РАЗМНОЖЕНИЯ РЕЧНОИ КАМБАЛЫ В ВОСТОЧНОИ ЧАСТИ БАЛТИИСКОГО МОРЯ}

\section{Н. Ф. Микельсаар}

Резюме

1. Основные места нереста камбалы в восточной части Балтийского моря находятся в глубоководных районах последнего, в общем западнее прибрежных вод Латвийской и Эстонской ССР. Отсюда молодая камбала рассеивается по всему латвийскому и эстонскому побережью на места нагула.

2. Кроме основных баз, места нереста камбалы встречаются и на ряде отмелей, вблизи полуостровов и островов. Такие нерестилища выявлены на южной окраине югозападного архипелага Фннляндии [8]. Собранные го ихтиопланктону материалы подтверждают существование не менее чем в четырех местах Финского залива (на восток до оконечности полуострова Юминда, $25^{\circ} 30^{\prime}$ в. д.) прибрежных нерестилищ (рис. 1). Предполагаемые места нереста камбалы распространены до $26^{\circ}$ в. д. (рис, 3). 
3. Икра камбалы на прибрежных нерестилищах ловилась на дне нли в придонных слоях воды, на глубине 4-22 (27) м, причем наиболее обильно она встречалась на глубнне 10 м (рис. 2), при температуре воды $3,0-6,7^{\circ} \mathrm{C}$ (преимущественно $4,7-6,7^{\circ} \mathrm{C}$ ) и солености 5,98-7,05\% (преимущественно 6,1-6,6\%). Возможно, что развитие большого процента икринок прекращается на первой стадии, и что в рассматриваемых условиях оплодотворение заканчивается в основном на стимулировании кратковременного партеногенетического развития.

4. Размеры икринок камбалы, нерестующей в грибрежных районах Финского залива, составляют от 0,83 до 1,20 мм, средний диаметр - 1,025 мм. Диаметр икринок у камбалы, нерестующей во впадинах, значительно больше, чем у береговой; их предельные размеры друг друга не покрывают.

5. В средних частях Балтийского моря, т. е. в районах впадин, нерест происходит в апреле и мае, а на прибрежных отмелях Финского залива - преимущественно в мае-июне. В годовом цикле развития гонад наблюдается большая индивидуальная вариация. Переход в третью стадию половой зрелости как у самцов, так и у самок наступает либо в августе, либо уже в конце июля, Последние самки с текущей икрой были пойманы в июне, последние самцы в V стадии - в конце июля (Финский залив) или в августе (у о. Сааремаа).

6. Половой зрелости самки прибрежнонерестующей камбалы достигают впервые в возрасте четырех лет, при длине в 18,5 см, самцы в возрасте трех лет, при длине 15,2 см или, возможно, еще меньшей.

7. Плодовитость прибрежнонерестующей камбалы в Финском заливе, т. е. общее число икринок в яичнике, составляло при длине рыбы (абс.) 18,5 см более 200 тысяч, при длине рыбы около 32 см - приблизительно $1-2$ миллиона (табл. 2).

8. Численное соотношение полов камбалы в популяциях колеблется в зависимости от различий в поведении полов; в нерестовых скоплениях наблюдается высокий процент самцов.

9. Следует полагать, что от продолжительности времени, потребного для развития камбалы восточной части Балтийского моря, начнная с оплодотворения икринок и кончая метаморфозом, в большой мере зависит судьба икринки и личинки. В противоречиях, развивающихся во взаимоотношениях степени развития икринок и личинок, и времени прибытия их в прибрежные или придонные условия можно усмотреть один из основных факторов в историческом образовании двух различающихся по биологии размножения группировок камбалы в восточной части Балтийского моря,

Ннститут зоологии и ботаники Академии наук Эстонской ССР
Поступила в редакцию

31 I 1957

\section{UBER DIE FORTPFLANZUNGSBIOLOGIE DER FLUNDER DER OSTLICHEN OSTSEE}

\section{N. Mikelsaar}

\section{Zusammenfassung}

1. Die Hauptlaichplätze der Flunder der östlichen Ostsee liegen an den tieferen Stellen ditses Meeres, im allgemeinen westlich von den küstennahen Gebieten der Lettischen und der Estnischen SSR. Von hier aus verbreiten sich die jungen Flunder über die gesamte Küstennähe dieser Länder.

2. Ausser den Hauptlaichgebieten gibt es auch Laichplätze der Flunder in verhältnismässig seichtem Wasser Halbinseln gegenüber und in der Nähe von Inseln. Derartige Laichplätze sind an der südlichen Grenze des südwestlichen Archipels von Finnland gefunden worden $\left.{ }^{[}\right]$.

Im Jahre 1949 genommene Ichthyoplanktonproben bestätigten das Vorhandensein küstennaher Laichplätze auch im Finnischen Meerbusen, wenigstens an vier Stellen, gegen Osten bis zur Spitze der Halbinsel Juminda $25^{\circ} 30^{\prime}$ östlicher Länge (Abb. 1). Diese Laichplätze erstrecken sich wahrscheinlich bis zum $26^{\circ}$ östlicher Länge (Abb. 3).

3. An diesen Plätzen wurden Flundereier in einer Tiefe von $4-27 \mathrm{~m}$, entweder am Meeresgrund oder dicht darüber schwebend gefangen. Die grössten Mengen fanden sich in einer Tiefe von $10 \mathrm{~m}$ (Abb. 2). Die Wassertemperatur variierte an diesen Stellen von 3,0 bis $6,7^{\circ} \mathrm{C}$ (meistens $4,7-6,7^{\circ} \mathrm{C}$ ), der Salzgehalt von 5,98 bis $7,05 \%$ (meistens $6,1-6,6 \%$ ).

Es ist möglich, dass bei einem grossen Prozent der Eier die Entwicklung im ersten Stadium aufhört und die Befruchtung unter den gegebenen Verhältnissen mit einer blossen Stimulation zu einer kurzzeitigen parthenogenetischen Entwicklung endet. 
4. Die Grösse der Eier der Küstenlaicher im Finnischen Meerbusen schwankt zwischen $0,83-1,20 \mathrm{~mm}$, durchschnittlich 1,025 mm. Der Durchmesser der Eier der Tiefen. laicher ist bedeutend grösser als bei den Küstenlaichern; die extremen Werte decken sich nicht.

5. Das Laichen der Flunder in den mittleren Teilen der Ostsee, d. h. im Gebiet der Tiefen vollzieht sich im April und Mai, an den küstennahen Laichplätzen des Finnischen Meerbusens aber hauptsächlich im Mai und Juni. Im Jahreszyklus der Geschlechtsdrüsenentwicklung zeigt sich eine beträchtliche individuelle Variabilität. Sowohl Männchen als Weibchen treten ins dritte Reifestadium im August, oder gar Ende Juli. Die letzten Weibchen mit fliessendem Laich werden im Juni, die letzten Männchen im V Stadium Ende Juli (im Finnischen Meerbusen) oder im August (an der Küste von Saaremaa) gefangen.

6. Die Weibchen der Küstenlaicher erreichen die Geschlechtsreife erstmalig im Alter von vier Jahren bei einer Länge (abs.) von $18,5 \mathrm{~cm}$, die Männchen im Alter von drei Jahren bei einer Länge von $15,2 \mathrm{~cm}$ oder noch weniger.

7. Die Zahl der reifen Eier in den Gonaden der Flunder im Finnischen Meerbusen betrug bei einem Weibchen von $18,5 \mathrm{~cm}$ Länge über 200000 , bei einer Länge von ungefähr $32 \mathrm{~cm}$ - annähernd 1-2 Millionen Stück (Tabelle 2).

8. Das Zahlenverhältnis der Geschlechter in den Populationen der Flunder schwankt im Zusammenhang mit ihrem verschiedenen Verhalten; in den Laichkonzentrationen sind die Männchen mit hohem Prozentsatz vertreten.

9. Es ist zu vermuten, dass das Schicksal der Eier und Larven der Flunder der östlichen Ostsee wesentlich von der Zeitdauer abhängt, die zu ihrer Entwicklung von der Befruchtung an bis zur Vollendung der Metamorphose erforderlich ist. In den Widersprüchen, herstammend aus dem Nichtzusammenfallen des Entwicklungsstadiums der Eier und Larven mit dem Zeitpunkt, wo sie die Küsten- oder Bodenverhältnisse erreichen, kann einer der wesentlichsten Faktoren für dỉe Gestaltung zweier in der Fortpflanzungsbiologie sich unterscheidender Gruppierungen gesehen werden.

Institut für Zoologie und Botanik der Akademie der Wissenschaften der Estnischen SSR 